\title{
Gender Disparities in Secondary Education in Bangladesh
}

\author{
Molla Huq(Corresponding Author) \\ Department of Econometrics and Business Statistics \\ Monash University, Victoria -3800, Australia \\ Tel: 61-3-9905-8454Ｅ-mail:molla.huq@buseco.monash.edu.au
}

\author{
Pk Md. Motiur Rahman \\ Institute of Statistical Research and Training (ISRT) \\ University of Dhaka, Dhaka-1000, Bangladesh \\ E-mail: pkrahman@isrt.ac.bd
}

\begin{abstract}
Enrolment and success rates are very crucial for any educational system in the world but they are more important for the developing countries like Bangladesh. Gender differences in enrolment and success rates are also emerging issues. This study investigated the enrolment and success rate's status in secondary educational system of Bangladesh along with internal efficiency rates involving completion rate, retention or survival rate, dropout rate and gender parity index. Some tests of hypotheses of homogeneity were also conducted. Among the findings higher female enrolment rate, lower female success rate, higher male completion rate, survival rate and higher female dropout rate were perceived along with different location, types of schools variations. Some policy implications were suggested with acknowledgement of some flaws in the female stipend Program in Bangladesh.
\end{abstract}

Keywords: Gender disparity, Enrolment rate, Success rate, Secondary Education, Bangladesh

\section{Introduction}

Bangladesh is one of the least developed countries of the world. It terms of human development index it ranks 137 among 177 countries (UNDP, 2006). But it has made notable progress in the education sector in the last two decades. A significant increase in enrolment rates in primary, secondary and tertiary levels of education has been perceived. Apart from the increase in enrolment rates, an important aspect of the recent growth in enrolment is the closure of the gender-gap in primary and secondary enrolment. The gender-gap was much wider even a decade ago. A small fraction of girl students completing primary education used to continue up to secondary education and the dropout rates for the girls was very higher than their male counterparts. However, remarkable progress is noticed in respect of female participation, continuation and reduction in dropout rates. Such progress in female participation in secondary education is mainly attributed to female-stipend Programs in rural areas of Bangladesh. Under this Program, all female students from grade 6 to 10 receive monthly stipends for their school participation. In addition to stipend money, school fees for female students are paid by the government to the respective schools. In order to achieve Millennium Development Goals, the government of Bangladesh has implemented food for education Program at the primary level and female stipend Program at the secondary level of education. Implementation of these Programs would therefore result in the elimination of gender disparities in the primary and secondary education as called for by the Millennium Development Goals.

Bangladesh has also made considerable progress in expanding educational facilities in the country. In the last two decades, the number of secondary schools has increased by two times. Along with the expansion of physical facilities, the availability of teachers has also improved. Ensuring adequate availability of educational facilities is necessary but not sufficient for enrolment, completion, survival and reduction of dropout in the secondary level education. The facilities must be accessible to the poor and females. This means that the facilities must be affordable for everyone without social and gender discriminations.

\section{Data and Methodology}

\subsection{Data Source}

The data originated from two different sources, firstly, national level data from Bangladesh Bureau of Educational Information and Statistics (BANBEIS) and Bangladesh Bureau of Statistics (BBS) and secondly, a sample survey conducted for "A Study of Secondary Education in Bangladesh and West Bengal" sponsored by The South Asian 
Network of Economic Research Institutes (SANEI). They surveyed a total of 104 secondary schools (High Schools) spread over Bangladesh. From each school, teachers, a sample of 10 students studying in grades 9 and 10 and a sample of 5 students who passed SSC examination in 2003 were also interviewed. The list of schools under the seven Secondary and Higher Secondary Education Boards was the universe. The sample data comprises of 485 SSC passed students across 8 Govt. high schools, 4 Cadet colleges, 82 Private but govt. aided and 4 Private but not govt. aided and 6 Private but Specially endowed schools.

\subsection{Tools of Data Analysis}

- Completion Rate: The completion rate is defined as the percentage of a cohort of pupil who enrolled in grade 6 of secondary education in a specific grade who could not reach the next grade in the next academic year and left school before holding annual examination.

- Survival Rate: The survival rate is defined as the percentage of a cohort of pupils who enrolled in the Grade 6 of Secondary education in a given-year and who eventually reach Grade 10. Its purpose is to measure the "holding power" and internal efficiency of an education system at secondary level. In other wards, it implies that the proportion of a pupil cohort that Completes Grade 9 and reaches Grade 10. It also indicates the magnitude of dropout before Grade 10. The survival rate approaching 100 percent signifies a high overall level of efficiency, while less than 100 percent indicates inefficiency due to grade repetition and drop-out. The survival rate may be also defined as the share of grade 10 enrolments in the total enrolment in each area or school. But it does not reflect the pattern of flow of students over a period; it serves only as an index of rates of survival in the school system over the period.

- Dropout Rate: The dropout rate is defined as the percentage of a cohort of pupils who enrolled in a specific grade but couldn't reach the next grade in next academic year. In the present context the difference in enrolment at the time of admission in February and at the time of annual examination in December was collected to estimate the dropout rates during one academic year.

- Gender Parity Index (GPI): GPI is the ratio of female to male enrolment rates. When the enrolment gender parity index (GPI) for enrolment shows a value equal to 1, female enrolment and male enrolment rates are equal. A value less than 1 indicates that proportionately less female than male have enrolled.

- Test of Homogeneity of Two Factors: The test statistic: $\chi^{2}=\sum_{i=1}^{r} \sum_{j=}^{c} \frac{O_{i j}^{2}}{E_{i j}}-N$, where O represents the observed frequencies and E represents the expected frequencies.

- Test of Homogeneity of more than Two Factors: We applied the analysis of variance to test the homogeneity of their achievements. The test statistic used was

$\mathrm{F}=$ Between mean square / Within mean square

which if $\mathrm{H}_{0}$ is true, has an F-distribution with $\gamma_{1}=k-1, \gamma_{2}=n-k$ degrees of freedom. The critical region is $\mathrm{F}>\mathrm{F}_{0.05}(\mathrm{c}-1, \mathrm{n}-\mathrm{c})$

\section{Gender Disparity in Enrolment and Success Rates}

We are going to discuss the scenario of gender disparity with respect to enrolment rates and success rates in secondary educational system in Bangladesh.

\subsection{Enrolment Rate: National level}

Enrolment rate is very important determinant of educational achievement of a country. According the Nath et al. (1999) the current school enrolment appeared to be the main predictor of basic education in Bangladesh while Raynor (2005) finds girls in Bangladesh are enrolling in a higher rate than the boys. So, a good discussion on enrolment status of Bangladesh should be addressed.

Gross enrolment rate at the secondary level of education is showing an increasing trend and the growth for female enrolment rate is higher than the male children. It was 57.46 percent for male and 42.54 percent for female in 1999. But the enrolment rate for male decreased to 51.52 percent, which for female it increased to 48.48 percent in 2003 (Table 1). The gender gap in enrolment rate has been gradually reducing. This is because each female student from grades 6 to 10 gets stipend from the government and other donor agencies. Government also provides tuition fees to the school for each female student. As a result of female stipend Program at the secondary school in rural areas, enrolment has steadily gained ground and enrolment rate for female is increasing gradually. But it has been found that many parents give priority to arrange marriage for their daughters instead of completing of secondary level education and this is reckoned as one of the main causes of dropout of female students. 
The estimated value of gender parity index (GPI) is less than 1 but it increases from 0.7403 in 1999 to 0.9410 in 2003. When the gender parity index (GPI) for enrolment shows a value equal to 1, female and male enrolment rates are equal. A value less than 1 indicates that proportionately less female than male have enrolled. However, GPI gradually approaching towards 1 indicating that gender disparity in enrolment is gradually reducing.

In a broad view, there has been a sharp increase in female enrollment in all phases of education in Bangladesh. Since independence Bangladesh has been achieving tremendous progress in female education though female education has not yet reached its goal of educating every single female in this country under the slogan "Education for all". From primary level to tertiary or above level female education has received greater public concern and became one of the burning issues accomplishing the task of educational progress among women in Bangladesh reducing the gender disparities. Not only in enrollment of female students but also the dramatic increase in the number of female educational institution and female teachers show us the evidence that government policy regarding the progress in female education is approaching its goal very slowly. Table 2 below shows us the enrollment of students in secondary schools from 1981-2002 (data of previous years were not available in any publication available in BANBEIS (note 1) at the time of data collection). In this table we can see that the enrollment percentage of females in secondary schools has shown a tremendous increase over these years and reached $52.8 \%$ in 2002 from $27.02 \%$ in 1981.

Though we have already had a data view and we understood how tremendously accelerated is female enrolment in comparison with their male counterparts, yet we are going to set a trend from the data which will say for itself about the almost monotonic increasing trend of percentages of female enrollment and almost monotonic decreasing trend of percentages of male enrollment over the years 1981-2002 at secondary level of education in Bangladesh. From figure 1 we can perceive the trends for males and females. The tremendous progress of female enrolment is to be noted compared to the diminishing trend of male enrolments.

The values of Gender Parity Index (GPI) shown in Table 2 indicate the increasing trend of female enrolment also. The values of GPI from the year 1981 to 1997 show increasing female enrolment over those years yet with male dominance. In those years female enrolment was much less than male enrolment. It is from 1998 when female enrolment exceeded male enrolment and till 2002 it is a dominating scenario of female enrolment.

\subsection{Success Rate: National Level}

Let's have a look on the present secondary educational success rate among the students, which may provide us an insight into the secondary educational realm. Figure 3 shows the Secondary School Certificate (S. S. C.) examination results of the whole country since independence to 2003 that is from 1972 to 2003, which has a trend of ups and downs with the highest pick at $1972(82.54 \%)$ and the lowest one at 1990 (31.13\%). In recent days that is from 1995 till 2003 the trend shows an almost decreasing pattern which actually indicates a downward rate of success of students at SSC level. Especially it seems that students in far previous years have shown to achieve better success at SSC level than the students of present days.

In Figure 2 we can see the results of Secondary School Certificate examination from 1990 to 2003 decomposed with respect to sex. If we set a trend line through the data then we may discover the idea that female success in SSC examination is totally reverse in comparison to their enrollment status. The result over the years 1990-2003 shows us the ups and downs in the trend and specially the almost decreasing trend part of female success from 1995 whereas their male counterparts had a almost increasing trend regarding success in passing SSC examination. Neither the data nor the data source states the reasons behind this trend yet we are to discover the determinations of this huge gender disparity existing in the present secondary educational level of Bangladesh.

We can very easily observe that female students are enrolling at a higher rate than the male students yet they don't do better in final SSC examination. Some critics state this situation this way that female enrollment has increased a lot but the comparative result in SSC examination with respect to males has decreased because female students get enrolled to enjoy the female stipend Program. Even though Raynor (2005) and Raynor and Wessen (2006) talks about the advantages of the stipend Program yet with the help of corrupted clerks female students take the advantage of female stipend Program. Though there has been three distinct undertakings to be signed before taking the stipend like student must get at least $40 \%$ marks in all exams, student must have at least $75 \%$ class attendance and she must not marry till grade 10 , yet they find a way in between without fulfilling the rules with the help of those corrupted clerks. This is why the result of female students are getting worse day by day though they consume a stipend which, of course, the male students are being deprived of.

\subsection{Enrolment Rate: Sample Schools}

To shed light on the factors affecting student enrolment let us perceive the facts inside the data.

\section{- Trends in Enrolment in the 104 Sample Schools by Locations and Type of Schools}

In this study the country has been divided in to four distinct areas namely Metropolitan, Municipality, Semi-urban and 
Rural areas. Let's have distinctive discussion on each of these areas regarding enrolment. Summing up all the locations the trend in per school enrolment by location is given in Figure 4. It is observed that there exist wide location variations in enrolment per school and proportion of female students to total enrolment. The enrolment per school was the highest in metropolitan area and lowest in rural area.

If we look at different location segments the higher rates of enrolments were observed in the metropolitan area, while the lower rates of enrolments were found to be in rural areas. In 1998 of the total enrolment 50.6 percent was male and the rest 49.4 percent was female. In 2000 the enrolment of female was 54 percent of the total enrolment. In 2003 the proportion of female students further increased to 56 percent. The value of gender parity index (GPI) of enrolment rate is greater than 1 which indicates that proportionately higher female have enrolled in metropolitan area in 2003 . The gender parity index increased from 0.98 in 1998 to 1.2 in 2000 and to 1.3 in 2003 . In Municipality area, the shares of female enrolment were 72 percent in 1998, 73 percent in 2000 and 69 percent in 2003, which shows a marginal decline in share of female students in 2003. Higher percentage of female enrolment was mainly due to selection of more than 50 percent girl's school in the sample. Moreover, 4 schools were selected from co-education system. Nevertheless, the value of gender parity index in the sample schools is decreasing gradually which means that female enrolment is reducing over the period in municipality areas. In Semi-Urban area the share of female students in enrolment increased from 61 percent in 1998 to 67 percent 2000 and then 69 percent in 2003. In Semi-Urban area, the selection of sample schools was biased towards girls' school, which resulted in higher share of female enrolments. In rural area the share of female students was 54 percent in 1998, 57 percent in 2000 and 59 percent in 2003 while this figure for male was 46 percent, 43 percent and 41 percent respectively. A noticeable feature is that there were wide differences in the participation rates of male and female. The main reason for these wide differences in the participation rates between male of female was implementation of female stipend Program along with tuition fee waiver particularly in rural areas. As a result, the proportion of female students increased from 54 percent in 1998 to 57 percent in 2000 and then to 59 percent in 2003. The value of the gender parity index for female enrolment rate was also greater than 1 in rural area. Trend in per school enrolment by location.

In all types of schools there has been a clear increasing trend in enrolment per school between 1998 and 2003. Sample comprised of 200 students of Cadet College, 1384 students of Govt. high school, 1460 students of Private (NGA) schools and 1170 students of Special Endowed School (SES). But the increase in enrolment in Govt. high school and Cadet College is not significant as there is no scope to increase the class size; while in other private schools there is no such limitation. But increase in enrolment per school was moderate and the private but govt. aided school illustrated first upward trend up to 2001 then it registered a downward trend. The private but not govt. aided and specially endowed schools showed clear and moderate increase in enrolment per school over the period. Trend in per school enrolment by type is shown in Figure 5.

It has been seen that the enrolment sample govt. high schools is gradually increasing the growth rate for male students per annum was 1.2 percent between 1998 and 2003, while this figure for female students was 2.2 percent and the difference in growth rate between and female has persisted during the period under review. The female enrolment as percentage to total enrolment was found to be 41 percent in 1998, 37 percent in 2000 and 36 percent in 2003 . The value of gender parity is less than 1 implies that proportionately fewer female than male enrolled in government high school. In sample cadet colleges there were 808 students in 1998, 832 in 2000 and 848 in 2003 and the corresponding enrolment per college was 202, 208 and 212 respectively. Actually, it is not wise to make any attempt to measure trend in enrolment in cadet colleges, as there is no scope for expansion of class size. In sample private but govt. aided schools the enrolment for female as percentage of total enrolment shows a slight improvement between 1998 and 2003 and it increased from 58 percent in 1998 to 61 percent in 2000 and 62 percent in 2003 . The enrolment in sample private but not govt.-aided schools has been increasing steadily and it has become more than double in 2003 compared to 1998. The annual growth rate of enrolment, over the period was estimated at about 28 percent. The share of female enrolment to total enrolment was 69 percent in 1998, 75 percent in 2000 and 71 percent in 2003. The main reason for higher percentage of female students was that out of 4 sample schools 2 were exclusively for girls and 2 were co-education system. In sample specially endowed schools more than 80 percent of the students were female because 2 girls and 4 under co-education system schools were in the sample. More precisely, it was 84 percent in 1998 as well as in 2000 and 82 percent in 2003 .

\subsection{Success Rate: Sample Schools}

- Distribution of SSC Passed Students by Locations and Types of Schools

The data in Table 8 reveals that the highest number of students who secured " $\mathrm{A}$ " belongs to municipality area though the respective number of metropolitan area is almost near and rural are places to third in that rank. Yet we feel despaired by having a look at the semi-urban area where no one got the highest grade. Among the other grades it has been observed that result of the students of municipality area dominates over the rest of the areas except for the grade " $\mathrm{A}$ " and "C" where metropolitan and rural areas owns the highest number respectively. That means students of metropolitan 
and municipality areas do well in SSC exam usually.

We also have tested whether result varies with location significantly which is given below

- Test for Homogeneity of Locations

Table 3 contains the scores obtained by students in four locations of SSC passed students.

The hypothesis corresponding to the problem that the locations are equal in achievement has the calculated value of $\mathrm{F}=$ 751.79 which falls in the critical region, we can reject the null hypothesis of equality of the means. Hence, the data provide sufficient evidence to indicate that the locations differ with respect to their achievement, which means result of students, varies with locations.

From Table 4 we observe that students of Cadet Colleges undoubtedly obtained the maximum number of " $\mathrm{A}^{+ \text {" though }}$ data were collected only on 200 students of Cadet College as compared to 1384 students of Govt. high school, 1460 students of Private (NGA) schools and 1170 students of Special Endowed School. It actually proves the credit of Cadet Colleges to build students to secured excellent results. Among other institutions we observe that Govt. High schools and Special Endowed Schools are doing very well to create students do well in SSC exam.

Again we tested the homogeneity of school types which is attached below

- Test for Homogeneity of School Types

Table 4 contains the scores obtained by students in five types of schools of SSC passed students. The hypothesis corresponding to the problem that the types of schools are equal in achievement has the calculated value of $F=7890.12$ which falls in the critical region, we can reject the null hypothesis. The data provide sufficient evidence to indicate that their achievement differ with respect to the types of schools, which also means that school type is a factor affecting result of students.

\section{Gender Disparity}

Asadullah, M, N. and Chaudhury, N (2006) mentioned that the gender disparity in education in Bangladesh has different dimension along with career path for females which, to a certain extent, linked with social, religious and economic values of Bangladesh while Raynor (2005) focuses on the attitudes of people of Bangladesh about the female education which is to blame for the gender disparity in education in Bangladesh. Whereas Chowdhury et al. (2002) finds that gender differences disappeared from enrolment at primary level. Maitra(2003) also asserts "...there is no gender differential in the probability of current school enrolment of children aged 6-12, girls have a significantly higher probability of continuing in school relative to boys". Even though our study investigated secondary education but we are going to express different opinion about the gender disparity in educational system of Bangladesh.

\subsection{Internal Efficiency Rates: National level}

Khandker(1996) examined school efficiency and perceived different attainment, failure and dropout rates for males and females but with low disparity. He also found that lower dropout rate for girls contrasts sharply with the household-level analysis.

In our case, the internal efficiency rate at the secondary level of education have been examined by estimating three important components of efficiency such as completion rate, dropout rate and survival rate of students by sex. The higher value of completion rate and survival rate signifies a higher level of efficiency, while higher value of dropout rate implies lower level of efficiency and higher social cost of education. Table 5 shows the internal efficiency by sex.

It reveals from the Table 5 that completion rate for female students is significantly lower than the male students and showing a decreasing trend between 1999 and 2003, while the dropout rate for females is much more higher than males. A decreasing trend is also noticed in respect of survival rate and coefficient of efficiency. It is worth mentioning that in spite of implementing female stipend Program in secondary education, the completion and survival rates for female are not encouraging. Only $14 \%$ female of a cohort of pupil who enrolled in grade 6 and who actually completed secondary education and reached grade 10 in 2003 which is low compared to the $20 \%$ male students. However, opposite scenario is observed in case of dropout rate where dropout rate is higher for female than the male students. There is a wide disparity between male and female in respect of completion rate, drop out rate and survival rate.

\subsection{Internal Efficiency Rates: Sample Schools}

- Survival Rates of Different Locations and Type of Schools by Sex

The survival rates are provided in the following two tables. We perceive that the notable feature is that in rural area the survival rate for female was much higher than that of male whereas in all areas except rural survival rate for male was higher than that of female. On the other hand, the highest (100\%) survival rate was observed in metropolitan areas and it was the lowest (64\%) in rural area.

The data on survival rate between 1998 and 2002 indicate the progressively diminishing survival of pupils in the system 
from grade 6 to grade 10 during the 4-year's period.

The survival rate for male pupils in government high school is 100 percent, which indicates no wastage due to repetition and dropout, but for female this rate was about 87 percent in government high school, 100 percent in Cadet College and specially endowed schools. Relatively lower survival rates both for male and female pupils were deserved in private but government aided and private but not aided schools. Thus the economic efficiency and resource utilization were optimal in government high school, Cadet College and specially endowed schools.

The survival rate in the sample schools appears to be much higher than that of national rate estimated by the BANBEIS. It is also higher for female particularly in private high school in rural areas and this higher survival rate is mainly due to implementation of female stipend Program from grade 6 to grade 12.

\section{- Dropout Rate by Locations and Types of Schools}

One of the prime concerns of the policy makers is the high dropout rate in secondary schools. The estimated rate by location and type of school is shown in Table 8 and Table 9 respectively.

The dropouts who leave school within one-year were the highest (26\%) for female students in rural area. This figure was 17 percent in semi-urban, 4.6 percent in municipality and less than one percent in metropolitan area. More than one-fourth of the total female students dropped out within one-year from rural schools. The same trend has been perceived from their male counterparts with different percentage points. On the other hand, highest proportion of students (11\% for male and $18 \%$ for female) dropped out from private but govt. aided schools. The dropout rate for female students was higher than that of male students except metropolitan area and specially endowed schools. From socio-economic view point, the students who leave school at the earlier stages receive only partial education and the majority of them are obviously ill-adapted to its social and economic environment.

\subsection{Gender disparities from the results of SSC of Sample Schools}

To investigate the gender disparity in educational attainment an in-depth survey on 485 students who passed SSC examination in 2003 was performed. The distribution of the sample SSC passed students by grade and sex in shown in Table 10. It is to be noted that students who failed in the examination were discarded from the analysis and that all the interviewed students actually passed the SSC examination in 2003. If we stare at the Table 9 we can see that out of 485 students only $7.2 \%$ got the top grade "A+" $(\mathrm{GPA}=5), 12.6 \%$ got the second highest grade "A" $(\mathrm{GPA}=4), 8 \%$ got "A-" $(\mathrm{GPA}=3.5), 29.7 \%$ got "B" $(\mathrm{GPA}=3)$, majority of the students $(40 \%)$ got "C" $(\mathrm{GPA}=2)$ and $2.7 \%$ got the lowest grade "D" $(\mathrm{GPA}=1)$. If we try to draw lines in the gender variation then we can see that only $8.5 \%$ of the male students and $6.1 \%$ of the female students secured "A+" which actually shows a slight better achievement of male students. Among both the male and female majority portion got grade "C" (36.9\% of male and $42.4 \%$ of female and $39.8 \%$ of both gender).

Of the total "A+" and "A" holders we can see that $54.3 \%$ and $54.1 \%$ belongs to the male students and $45.7 \%$ and 46.4 $\%$ to the female students where we can see the dominance of the male students. And in case of the rest of the categories of results female students dominate over male students. And among males and females who achieved higher grades we perceive an almost complete dominance by male students. For example, among the 35 students who got A+ 19 of them are males and 16 are females, among 61 A's 33 is the number of male students and 28 was of females. Among the students of metropolitan area only 1 male student secured the highest grade "A+" whereas 8 female students obtained that grade. This type of performance dominance of female students over male students has been observed over other categories of grades except grade "A" where 16 male students secured it with compared to 10 female students. In municipality area we perceive the same picture of female students doing better in performing better result in all the categories of grades except the highest grade "A+" where 12 male students secured this grade with comparison of 7 female students. In semi-urban area the picture is clearer that female students did better than their male counterparts in all the categories of result grade though nobody from the semi-urban area secured the highest grade "A+". From the same illustration we find in rural area male students dominated in all the grade categories except the grades " $\mathrm{C}$ " and "D".

\section{- $\quad$ Test for Homogeneity of Gender}

To investigate whether the two groups, male and female, are homogenous with respect to the 6 categories we have the null hypothesis that the male and female groups are homogenous. Therefore, we have $\chi^{2}=\sum_{i=1}^{2} \sum_{j=1}^{6} \frac{O_{i j}^{2}}{E_{i j}}-N=49.876$

The tabulated value of $\chi_{5,0.05}^{2}=11.0705$

From the above analysis we see that the value of Chi-square is significant at $5 \%$ level of significance and hence we can reject the null hypothesis of homogeneity. This means that on the basis of the available data, it would be unreasonable to 
treat the groups homogenous. Therefore, we can conclude that the result of S.S.C. with 6 different categories is significantly different for the male and female groups.

\section{Summary and Conclusion}

The relationship between gender and education is complex and dynamic. In the past, these differences were formalized into separate provision, designed; it was argued to prepare girls and boys for their different lives as adults. Today, while educational policy no longer recommends separate provision, more hidden processes can still result in inequality.

Female enrolment has been increased in all phases of education in Bangladesh. From the enrollment of students data in secondary schools all over Bangladesh from 1981-2002, we can see that the enrolment percentage of females in secondary schools has shown a tremendous increase over these years and reached $52.8 \%$ in 2002 from $27.02 \%$ in 1981 . The values of Gender Parity Index (GPI) indicate the increasing trend of female enrolment also.

It is observed that there exist wide location variations in enrolment per school and proportion of female students to total enrolment. The enrolment per school was the highest in metropolitan area and lowest in rural area. In metropolitan area there was an increasing trend in enrolment per school, while the trend in semi-urban and rural areas registered a declining trend from 2001 to 2003. In municipality area there was a mixed trend in enrolment per school.

In all areas except rural survival rate for male was higher than that of female. On the other hand, the highest survival rate for male was observed in metropolitan areas and it was the lowest in rural area. This means internal efficiency and holding power of male students in rural school is very low. For female, the highest was in metropolitan area and the lowest holding power was found to be in semi-urban area. However, in all respects the survival rate in metropolitan school is greater than any other locations. This rate ranked second in municipality area.

The survival rates of govt. high school, Cadet College, private but govt. aided, private but not govt. aided and specially endowed schools were key indicators of internal efficiency. The highest survival rate for male was observed in govt. high school and the lowest in private but not govt. aided whereas the highest survival rate for female was observed in Cadet Colleges and the lowest in private but govt. aided schools. That's how the economic proficiency and excellence were superb in government high school, Cadet College and specially endowed schools.

The dropout rate was the highest for female students in rural area and the lowest was less than one percent in metropolitan area. For male students the picture was almost same with changes in percentages. The dropout rate for female students except metropolitan area and specially endowed schools was higher than that of male students. From socio-economic viewpoint, the students who leave school at the earlier stages receive only partial education and the majority of them are obviously ill adapted to its social and economic environment.

To sum up, the enrolment in metropolitan and municipality areas has been continuously increasing, while decreasing trend is noticed in semi-urban and rural areas. The survival rates in semi-urban and rural areas are found to be lower as compared to metropolitan and municipality areas. The students-teacher ratios in semi-urban and rural areas are much higher than those in metropolitan and municipality areas.

The SSC results, which represents success rate, shows us that female success in SSC examination is totally reverse in comparison to their enrollment status. The result over the years 1990-2003 shows us the almost decreasing trend part of female success from 1995 whereas their male counterparts had a almost increasing trend regarding success in passing SSC examination.

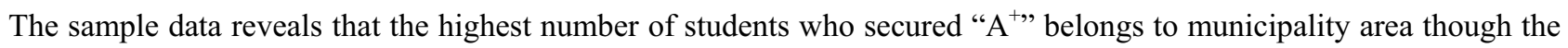
respective number of metropolitan area is almost near and rural are places to third in that rank. That means students of metropolitan and municipality areas do well in SSC exam usually.

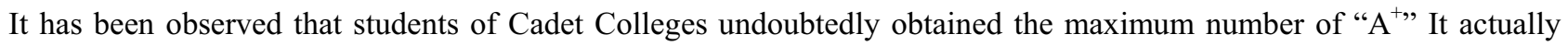
proves the credit of Cadet Colleges to build students to secure excellent results. Among other institutions we observe that Govt. High schools and Special Endowed Schools are doing very well to create students do well in SSC exam.

Male students dominated in achieving higher grades (" $\mathrm{A}$ " and " $\mathrm{A}$ ") whereas female students dominated in getting relatively lower grades (“A”, "B", "C" and "D”).

Through the test of homogeneity we found, on the basis of the available data, it would be unreasonable to treat the sex groups homogenous. We can conclude that the result of S.S.C. with 6 different categories is significantly different for the male and female groups. And it is easily perceived from the data of our sample survey that female students show better performance as compared to their male counterparts at metropolitan, municipality and semi-urban areas. Only at rural area they both perform almost the same.

Finally, we can very easily observe that female students are enrolling at a higher rate than the male students yet they don't do better in final SSC examination. Some critics state this situation this way that female enrollment has increased a lot but the comparative result in SSC examination with respect to males has decreased because female students get 
enrolled to enjoy the female stipend Program. With the help of corrupted clerks female students take the advantage of female stipend Program. They find a way without fulfilling the rules of stipend with the help of those corrupted clerks. This is why the result of female students are getting worse day by day though they consume a stipend which is not given to male students.

Though we have critics of the holes of female stipend Program yet it turned out to be an inspiration to the female students of Bangladesh. We have to remember equity for girls means equity for everyone. By following gender equity guidelines to improve education, it is improved for boys as well as for girls. The goal of better serving girls through female stipend does not entail neglecting or suppressing boys. By putting boys and girls on an equal plane, the relatively increased valuing of girls will also benefit boys by informing them of the strengths, capabilities and contributions of girls and women. This, in turn, may help decrease the pressure many boys feel to conform to the traditional roles, behaviors and ways of thinking. Eventually, the stereotypes may be counteracted and eliminated, so education may begin to be more gender balanced.

\subsection{Policy Implications}

- Govt. should stop corruption of administrative people who are related to stipend Program in rural schools to increase female success rate in SSC exam.

- Female students are enrolling at a higher rate than male students at this point of time, so govt. should now promote male students in rural areas as well by keeping the female enrolment steady.

- Schools in rural areas have lower survival rate and higher drop out rate. Govt. should take initiatives to increase survival rate in those areas.

- If possible govt. should establish more Cadet Colleges and Govt. High Schools or at least increase the seats in those institutes without compromising the quality of educational environment.

\section{Acknowledgment}

The authors would like to thank the seminar participants at Institute of Statistical Research and Training (ISRT), University of Dhaka, Bangladesh.

\section{References}

Ahmed, M., Chakrabarty, S., Sengupta, S. and Rahman, P. M. (2004). A Study of Secondary Education in Bangladesh and West Bengal. Preliminary Draft, A Study Sponsored by the South Asian Network of Economic Research Institutes (SANEI).

Asadullah, M, N. and Chaudhury, N (2006). Religious Schools, Social Values and Economic Attitudes: Evidence from Bangladesh. Working paper no. 139, QEH working paper series.

BANBEIS (1993). Bangladesh Educational Statistics 1993

BANBEIS (1994). Bangladesh Educational Statistics 1994

BANBEIS (1998). Bangladesh Educational Statistics 1998

BANBEIS (1999). National Education Survey (Post-Primary), Final Report

BANBEIS (2000). Bangladesh Educational Statistics 2000

BANBEIS (2001). Pocket Book on Educational Statistics 2001

BANBEIS (2002). Statistical Profile on Education in Bangladesh 2002

BANBEIS (2003). Pocket Book on Educational Statistics 2003

BANBEIS (2003). Bangladesh Educational Statistics 2003

BANBEIS (2004). Pocket Book on Educational Statistics 2004

Bangladesh Bureau of Statistics (2003). Statistical Yearbook of Bangladesh'2001.

Bangladesh Govt. Press (1978a). Annual Report on Public Instruction for the Year 1970-71.

Chowdhury, S. M. (1988) Introduction to Statistical Theory, Part-2, Ilmi Kitab Khana, Lahore, Pakistan. 297-321.

Chowdhury, A. M. R., Nath, S. R., and Choudhury, R. (2002). Enrolment at Primary Level: gender difference disappears in Bangladesh. International Journal of Educational Development,22, 191-203.

Human Development Report (2006). http://hdr.undp.org/hdr2006/statistics/ (accessed $3^{\text {rd } J u l y, ~ 2007) ~}$

Khandker, S.R. (1996).Education Achievements and School Efficiency in Rural Bangladesh, World Bank - Discussion Papers 319, World Bank. 
Maitra, P. (2003). “Shchooling and Educational Attainment: Evidence from Bangladesh. Education Economics, Vol. 11, No. 2, 129-153.

McNabb, R., Pal, S. and Sloane, P. (2002). "Gender Differences in Educational Attainment: The Case of University Students in England and Wales" Economica, 69, 481-503.

Nath, S. R. and Sylva, K (1999). Raising Basic Education Levels in Rural Bangladesh: The Impact of a Non-formal Education Program. International Review of Education, 45, No.1, 5-26.

Raynor, J. (2005). Educating girls in Bangladesh: watering a neighbour's tree?. Beyond Access: Transforming Policy and Practice for Gender Equality in Education, Oxfam publication. Online link: http://www.oxfam.org.uk/what_we_do/resources/downloads/BA_6.pdf (accessed on 26th July, 2007).

Raynor, J. and Wesson, K. (2006). The Girls' Stipend Program in Bangladesh. Journal of Education for International Development 2:2. Retrieved from http://www.equip123.net/JEID/articles/3/Bangladesh.pdf (accessed on 26th July, 2007).

\section{Notes}

Note 1. Bangladesh Bureau of Educational Information and Statistics (BANBEIS)

Table 1. Gross Enrolment Rate at Secondary Level by Sex

\begin{tabular}{|l|l|l|l|}
\hline \multirow{2}{*}{ Year } & \multicolumn{2}{|l|}{ Gross Enrolment Rate (\%) } & \multirow{2}{*}{ GPI* } \\
\cline { 2 - 4 } & Male & Female & \\
\hline 1999 & 57.46 & 42.54 & 0.7403 \\
\hline 2000 & 55.13 & 44.87 & 0.8139 \\
\hline 2001 & 53.77 & 46.23 & 0.8598 \\
\hline 2002 & 51.84 & 48.16 & 0.9290 \\
\hline 2003 & 51.52 & 48.48 & 0.9410 \\
\hline
\end{tabular}

Source: BANBEIS (2004).

*Gender Parity Index (GPI) is the ratio of female to male enrolment rates. 
Table 2. Student Enrollment in Secondary Schools of Bangladesh by Sex, 1981-2002

\begin{tabular}{|c|c|c|c|c|}
\hline Year & Total & Female & Female $\%$ & GPI \\
\hline 2002 & 7420358 & 3915654 & 52.76907 & 1.1173 \\
\hline 2001 & 7154712 & 3756660 & 52.5061 & 1.1055 \\
\hline 2000 & 7027111 & 3670097 & 52.22768 & 1.0933 \\
\hline 1999 & 6620845 & 3409728 & 51.49989 & 1.0619 \\
\hline 1998 & 6144925 & 3119704 & 50.76879 & 1.0312 \\
\hline 1997 & 5492114 & 2580578 & 46.98697 & 0.8863 \\
\hline 1996 & 5021390 & 2327758 & 46.35685 & 0.8642 \\
\hline 1995 & 4620769 & 2135973 & 46.22549 & 0.8596 \\
\hline 1994 & 4088742 & 1858222 & 45.44728 & 0.8331 \\
\hline 1993 & 3809515 & 1680028 & 44.10084 & 0.7889 \\
\hline 1992 & 3463236 & 1478031 & 42.67774 & 0.7445 \\
\hline 1991 & 2943473 & 994947 & 33.8018 & 0.5106 \\
\hline 1990 & 2748350 & 929091 & 33.80541 & 0.5107 \\
\hline 1989 & 2628036 & 871769 & 33.17188 & 0.4964 \\
\hline 1988 & 2542316 & 830676 & 32.67399 & 0.4853 \\
\hline 1987 & 2473911 & 787869 & 31.8471 & 0.4673 \\
\hline 1986 & 2345166 & 744149 & 31.73119 & 0.4648 \\
\hline 1985 & 2274950 & 719632 & 31.63287 & 0.4627 \\
\hline 1984 & 2182006 & 682074 & 31.25903 & 0.4547 \\
\hline 1983 & 2148412 & 671573 & 31.25904 & 0.4547 \\
\hline 1982 & 2129478 & 656232 & 30.81657 & 0.4454 \\
\hline 1981 & 1970075 & 532299 & 27.01923 & 0.3702 \\
\hline
\end{tabular}

Source: BANBEIS (2003, 2002, 2001, 2000, 1999, 1998, 1994, 1993, 1992, 1986).

Table 3. Distribution of Sample SSC Passed Students by Grade and Area

\begin{tabular}{|c|c|c|c|c|c|}
\hline \multirow{2}{*}{ Grades } & \multicolumn{4}{|l|}{ Location } & \multirow{2}{*}{ Total } \\
\hline & Metropolitan & Municipality & Semi-urban & Rural & \\
\hline $\mathrm{A}+$ & 101 & 105 & 0 & 43 & 249 \\
\hline A & 1280 & 424 & 16 & 88 & 1808 \\
\hline A- & 135 & 179 & 7 & 98 & 419 \\
\hline B & 312 & 334 & 65 & 254 & 965 \\
\hline $\mathrm{C}$ & 33 & 197 & 88 & 449 & 767 \\
\hline $\mathrm{D}$ & 0 & 6 & 35 & 52 & 93 \\
\hline Total & 1861 & 1245 & 211 & 984 & 4301 \\
\hline
\end{tabular}


Table 4. Distribution of Sample SSC Passed Students by Grade and Type of School

\begin{tabular}{|c|c|c|c|c|c|}
\hline \multirow{2}{*}{ Grades } & \multicolumn{5}{|c|}{ Types of Schools } \\
\hline & Govt. High & Cadet College & Private (GA) & Private (NGA) & Special ES \\
\hline $\mathrm{A}^{+}$ & 50 & 117 & 0 & 1 & 81 \\
\hline A & 729 & 74 & 92 & 37 & 876 \\
\hline A- & 116 & 8 & 138 & 1 & 156 \\
\hline B & 394 & 2 & 485 & 37 & 47 \\
\hline $\bar{C}$ & 95 & 0 & 652 & 10 & 10 \\
\hline $\mathrm{D}$ & 0 & 6 & 93 & 0 & 0 \\
\hline Total & 1384 & 201 & 1460 & 86 & 1170 \\
\hline
\end{tabular}

Table 5. Internal Efficiency Rates at the Secondary Level (Grade 6-10) in School

\begin{tabular}{|l|l|l|l|l|l|}
\hline \multirow{3}{*}{ Year } & \multirow{4}{*}{ Sex } & \multicolumn{3}{|l|}{ Internal Efficiency Rates (\%) } \\
\cline { 3 - 6 } & $\begin{array}{l}\text { Completion } \\
\text { Rate }\end{array}$ & $\begin{array}{l}\text { Dropout } \\
\text { Rate }\end{array}$ & $\begin{array}{l}\text { Survival } \\
\text { Rate }\end{array}$ & $\begin{array}{l}\text { Co-efficient } \\
\text { of efficiency }\end{array}$ \\
\hline \multirow{4}{*}{1999} & Both Sexes & 35.32 & 64.68 & 62.30 & 40.3 \\
\cline { 2 - 6 } & Male & 38.51 & 61.49 & 62.55 & 44.1 \\
\cline { 2 - 6 } & Female & 31.72 & 68.28 & 61.91 & 36.0 \\
\hline \multirow{3}{*}{2000} & Both Sexes & 28.24 & 71.76 & 65.37 & 32.2 \\
\cline { 2 - 6 } & Male & 32.33 & 67.67 & 66.19 & 38.0 \\
\cline { 2 - 6 } & Female & 23.89 & 76.11 & 64.00 & 26.5 \\
\hline \multirow{3}{*}{2002} & Both Sexes & 17.16 & 82.84 & 57.27 & 25.2 \\
\cline { 2 - 6 } & Male & 20.27 & 79.73 & 58.65 & 24.0 \\
\cline { 2 - 6 } & Female & 13.98 & 86.02 & 55.67 & 15.8 \\
\hline \multirow{3}{*}{2003} & Both Sexes & 24.79 & 75.21 & 57.89 & 28.2 \\
\cline { 2 - 6 } & Male & 30.87 & 69.13 & 61.75 & 35.4 \\
\cline { 2 - 6 } & Female & 19.23 & 80.77 & 54.31 & 21.8 \\
\cline { 2 - 6 } & Both Sexes & 16.57 & 83.43 & 49.38 & 20.2 \\
\cline { 2 - 6 } & Male & 19.53 & 80.47 & 50.75 & 23.7 \\
\cline { 2 - 6 } & Female & 13.74 & 86.26 & 48.30 & 16.7 \\
\hline
\end{tabular}

Source: BANBEIS (2004)

Table 6. Survival Rates by Location and Sex

\begin{tabular}{|l|l|l|}
\hline \multirow{2}{*}{ Location } & \multicolumn{2}{|l|}{ Survival Rate (\%) } \\
\cline { 2 - 3 } & Male & Female \\
\hline Metropolitan & 100.0 & 98.0 \\
\hline Municipality & 98.6 & 86.2 \\
\hline Semi-Urban & 86.0 & 72.1 \\
\hline Rural & 64.3 & 83.1 \\
\hline
\end{tabular}


Table 7. Survival Rates by Type of School and Sex

\begin{tabular}{|l|l|l|}
\hline \multirow{2}{*}{ Type of School } & Survival Rate (\%) \\
\cline { 2 - 3 } & Male & Female \\
\hline Govt. high School & 100.0 & 86.6 \\
\hline Cadet College & 97.4 & 100.0 \\
\hline Private but Govt. Aided & 65.8 & 71.9 \\
\hline Private but not Govt. Aided & 57.5 & 77.3 \\
\hline Specially Endowed School & 91.5 & 99.8 \\
\hline
\end{tabular}

Table 8. Dropout Rate by Location Between February and December 2003

\begin{tabular}{|l|l|l|}
\hline \multirow{2}{*}{ Location/Area } & \multicolumn{2}{|l|}{ Dropout Rate (\%) } \\
\cline { 2 - 3 } & Male & Female \\
\hline Metropolitan & 1.2 & 0.71 \\
\hline Municipality & 4.4 & 4.6 \\
\hline Semi-Urban & 5.2 & 16.9 \\
\hline Rural & 13.9 & 25.5 \\
\hline
\end{tabular}

Table 9. Dropout Rate Type of School Between February and December 2003

\begin{tabular}{|l|l|l|}
\hline \multirow{2}{*}{ Type of School } & \multicolumn{2}{|l|}{ Dropout Rate (\%) } \\
\cline { 2 - 3 } & Male & Female \\
\hline Govt. high School & 1.4 & 2.40 \\
\hline Cadet College & 1.3 & 5.60 \\
\hline Private but Govt. Aided & 10.7 & 17.50 \\
\hline Private but not Govt. Aided & 4.7 & 2.60 \\
\hline Specially Endowed School & 3.7 & 0.51 \\
\hline
\end{tabular}

Table 10. Distribution of Sample SSC Passed Students by Grade and Sex (Left: Grade based, Right: Sex based)

\begin{tabular}{|c|c|c|c|c|c|c|}
\hline Grade & \multicolumn{2}{|c|}{ Male } & \multicolumn{2}{|c|}{ Female } & \multicolumn{2}{|c|}{ Total } \\
\hline $\mathrm{A}^{+}$ & $(8.5 \%)$ & $(54.1 \%)$ & $(6.1 \%)$ & $(45.7 \%)$ & $(7.2 \%)$ & $(100 \%)$ \\
\hline A & $(14.8 \%)$ & $(54.1 \%)$ & $(10.7 \%)$ & $(46.4 \%)$ & $(12.6 \%)$ & $(100 \%)$ \\
\hline $\mathrm{A}^{-}$ & $(7.6 \%)$ & $(43.6 \%)$ & $(8.4 \%)$ & $(56.4 \%)$ & $(8.0 \%)$ & $(100 \%)$ \\
\hline B & $(30.9 \%)$ & $(47.9 \%)$ & $(28.6 \%)$ & $(52.1 \%)$ & $(29.7 \%)$ & $(100 \%)$ \\
\hline $\mathrm{C}$ & $(36.9 \%)$ & $(42.5 \%)$ & $(42.4 \%)$ & $(57.5 \%)$ & $(39.8 \%)$ & $(100 \%)$ \\
\hline $\mathrm{D}$ & $(1.3 \%)$ & $(23.1 \%)$ & $(3.8 \%)$ & $(76.9 \%)$ & $(2.7 \%)$ & $(100 \%)$ \\
\hline Total & $(100 \%)$ & $(46 \%)$ & $(100 \%)$ & $(54 \%)$ & $(100 \%)$ & $(100 \%)$ \\
\hline
\end{tabular}




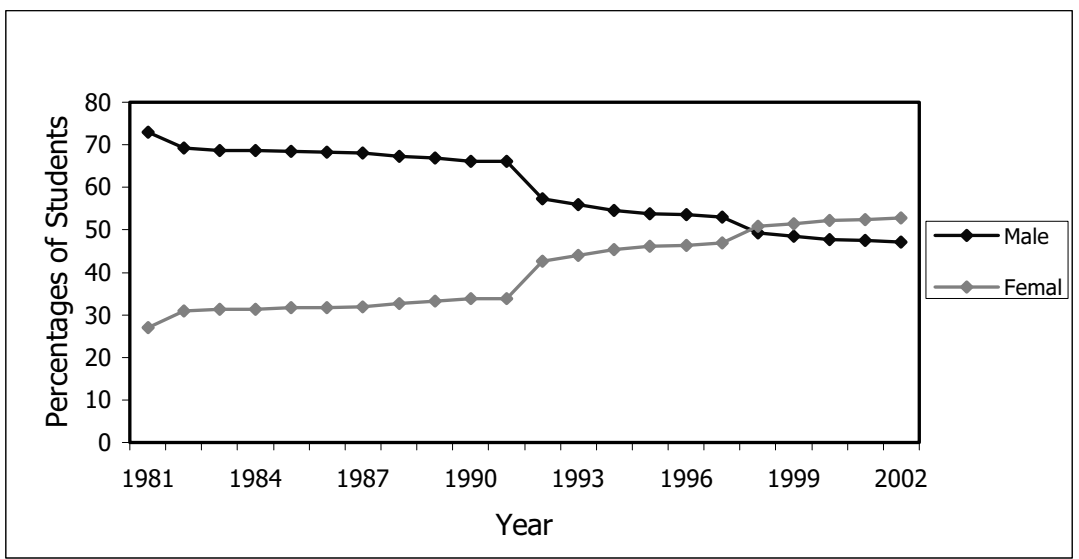

Figure 1. Percentages of student enrollment by sex

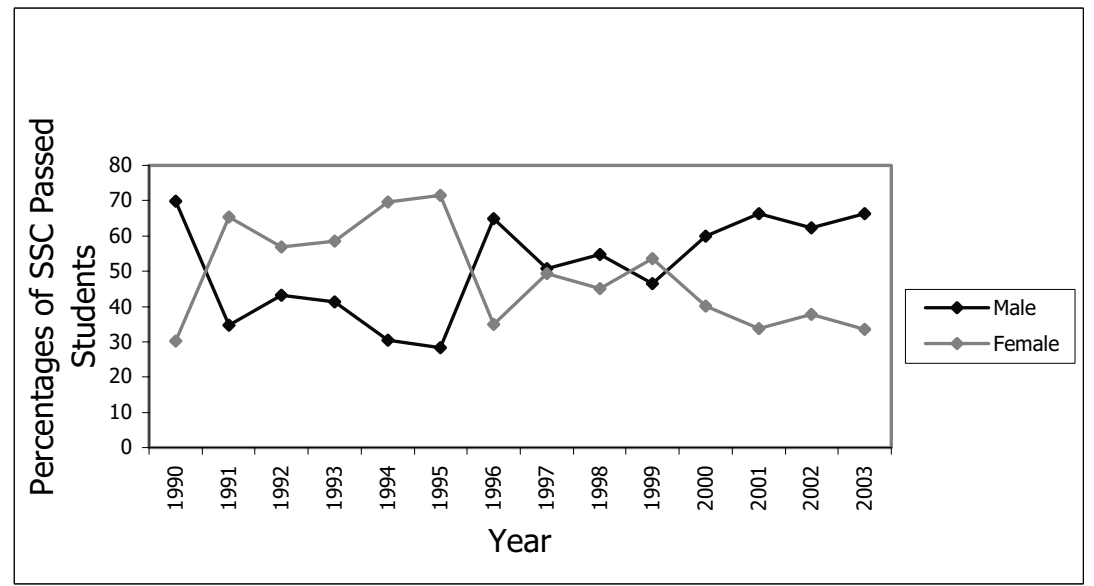

Figure 2. Percentages of SS passed students by sex

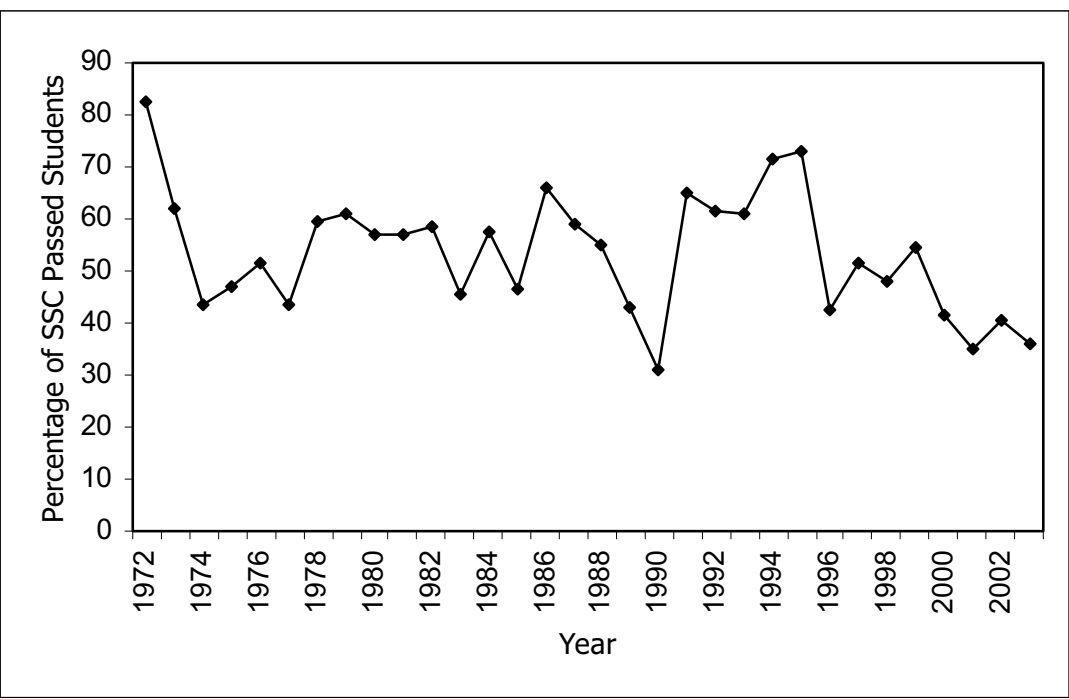

Figure 3. Percentage of SSC passed students of Bangladesh over the years 1972-2003

Data source: BANBEIS $(2003,1992,1986)$. 


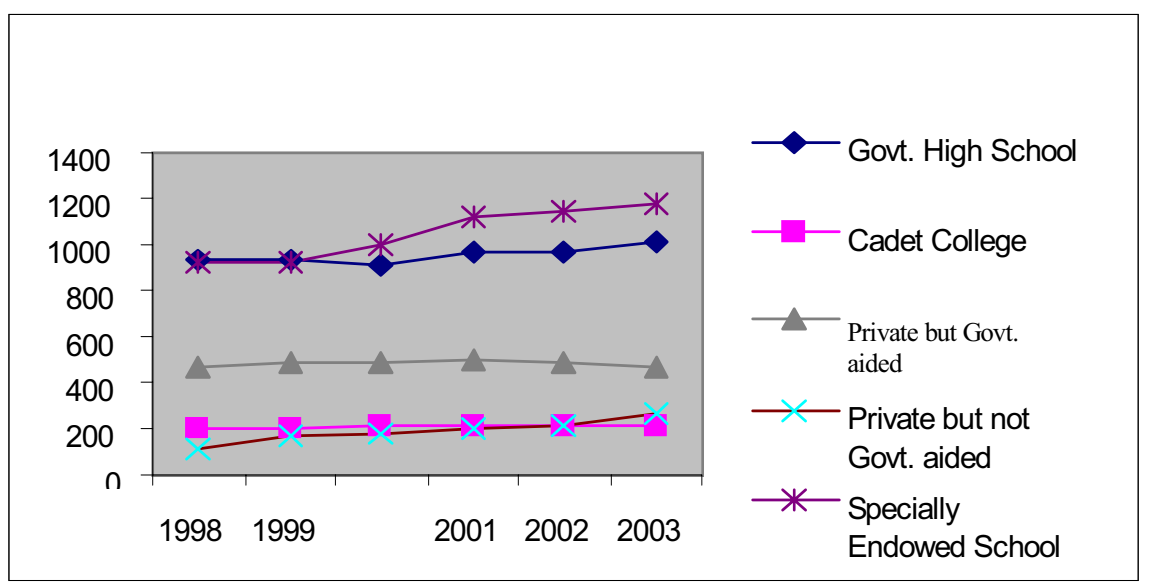

Figure 4 . Trend in school enrolment by type

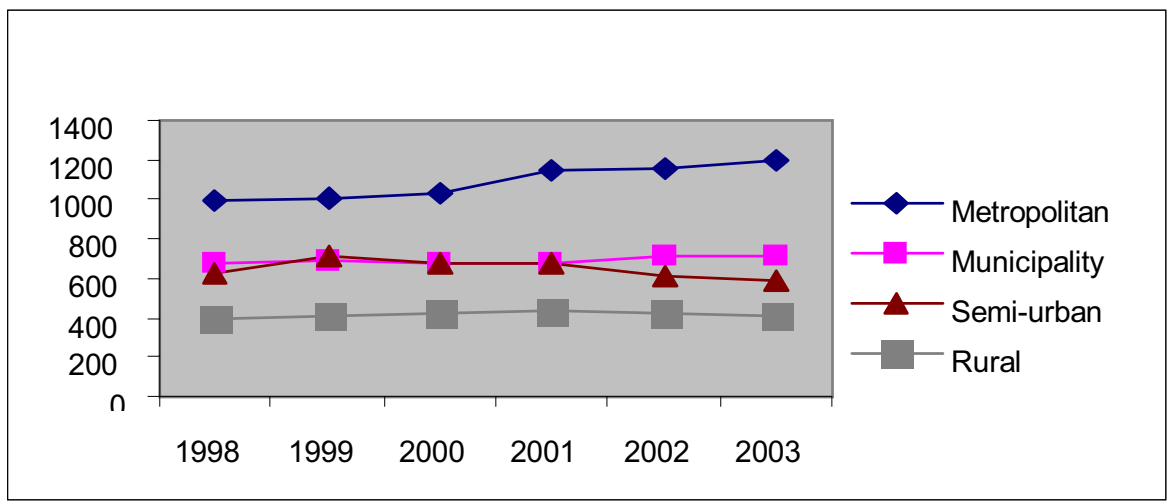

Figure 5. Trend in enrolment per school by location 